\title{
11 Horizontal Learning in Medieval Italian Canonries
}

\author{
Neslihan Şenocak
}

\begin{abstract}
In Italy, the organization of churches and worship evolved differently than other parts of Europe. From the sixth century onwards, Italian dioceses were further divided into districts of worship known as plebium, where the pastoral authority belonged to a baptismal church called pieve (plebs). Both the cathedral in the city and the pievi in the countryside were served by multiple clergy, called canons, who lived together in a residence (domus or canonica) attached to their church. This communal life facilitated horizontal learning among canons, while the liturgical services, and in particular the Divine Office, served as the major platform for the transmission of knowledge from experienced canons to those beginning their clerical career.
\end{abstract}

Keywords: Medieval/Middle Ages, Medieval Italy, liturgy, canons, teaching, learning

This volume on horizontal learning puts under the spotlight the kind of learning not acquired within the formal setting of a school, where knowledge is passed vertically from a professional teacher to student and where the teacher and student are not each other's peers. Horizontal learning presumes the existence of a community, and it can be defined as the knowledge passed from one peer to the other within the confines of that community. One can, of course, argue that these descriptions of vertical and horizontal learning are not mutually exclusive. The school setting itself is a kind of hybrid: there, students learn not only from a teacher but also from one another. Schools facilitate learning from peers by engendering a community, and

Long, Micol, Tjamke Snijders, and Steven Vanderputten (eds), Horizontal Learning in the High Middle Ages: Peer-to-Peer Knowledge Transfer in Religious Communities. Amsterdam, Amsterdam University Press 2019 DOI: 10.5117/9789462982949/CH11 
by providing a common timetable and a common space, within which the act of learning takes place. To study horizontal learning among the religious we need to examine the religious communities and assess their daily organization and structure for the opportunities they present for the acquisition of peer-based learning.

While the majority of the contributions in this volume turn to the monastery as a community of horizontal learning, I will here examine Italian clerical communities. In many ways, Italy sets a unique example. Unlike the rest of Europe, care of souls in Italy before the fourteenth century was largely organized and carried out by churches served by multiple clergy rather than by parish churches serviced by a single priest. The clerical community in these collegiate churches lived in a residence attached to the church, today still called by its medieval name canonica, i.e., the place where canons lived, sometimes also referred to in medieval documents as domus. In this particular Italian context, canon does not mean a member of an order of canons regular but instead simply means a member of a residential community of clergy who were attached to a church, regardless of whether they followed a Rule or not. We see this kind of communal life of clergy in Italy in the cathedrals, collegiate churches, and in pievi. These three ecclesiastical institutions were spaces of horizontal learning on account of the fact that the clergy ate, slept, and prayed together. They followed a common timetable within a common space. The vast majority of the pastoral clergy in Italy lived in some form of collegiate church, particularly until the end of the thirteenth century. The exceptions would be clergy who served in the private churches and, later, those who served in the emerging parishes, who might live on their own next to the parish church. ${ }^{1}$

I mentioned above the two conditions necessary for people to learn from their peers: a common space, where peers frequently meet each other; and a common schedule, which allows them to see each other at designated times. To these two we can add a third: a daily cycle of communal performances or rites that provide the proper setting for the transmission of knowledge to take place, allowing peers to observe, learn from, and correct one another. The life of the vast majority of clergy in medieval Italy from the fifth century to the fourteenth was designed in such a way as to provide an optimal environment for horizontal learning to take place, with all of the three conditions mentioned above, namely, the space, time, and a regular cycle of communal rites.

1 For a more in-depth discussion and evidence on the common life of clergy in Italy see $\mathrm{La}$ vita comune del clero nei secoli XI e XII, and Poggiaspalla, La vita comune del clero. 


\section{Pieve and its Clerical Community}

Among these three forms of clerical communities present in medieval Italy, pieve was the most common. From the seventh century onwards, all Italian dioceses were divided into smaller administrative districts, where each had one pieve (lat. plebs), that is, a head church (and at the same time a baptismal church), overseeing a number of dependent churches in its own district, its piviere (lat. plebatum). ${ }^{2}$ Medieval documents refer to such dependent churches as simply ecclesiae or cappellae. Pievi were served by multiple clergy and offered full church services, as opposed to the dependent chapels (which later on gained their independence from the pieve to become the parish churches) that offered no baptism, penance, and often no regular Sunday sermon. While each diocese had only one cathedral and a few collegiate churches, it would have a high number of pievi. Although historians did not study pievi as canonries, it is nevertheless well known that the pievi often had an attached canonica, where the clergy serving at the pieve lived a communal life and were referred to in the medieval records as canons. Therefore pieve can be also a type of canonry, and in the Italian-speaking historiography they are referred to as canonicas plebanales. ${ }^{3}$

The system of pieve, as a setting where the pastoral clergy was trained, is special to Italy and is not observed elsewhere in Europe, where the parish churches, being at the same time baptismal churches, offered in effect all the pastoral services. It appears that at least one of the reasons, perhaps the most important one, why such a diocesan organization developed in Italy was the opportunity it provided for the young clergy to learn from the old by living in a communal setting. It is not known exactly when this system was established, but we know that it existed as early as the sixth century. In 529, the French bishops, gathered in Vaison, praised the Italian pievi for providing a sustainable system of clerical training:

The priests established in the parishes, according to the custom that is observed in all of Italy, accept young lectors to live with them in the same house, and there the young men are nourished spiritually, as they learn

2 The fundamental literature on pieve is in Italian. See Forchielli, La pieve rurale; Violante, 'Che cos'erano le Pievi?', 429-438. The contributions in Pievi e parrocchie in Italia nel Basso Medioevo are particularly relevant and set the field of pieve studies in Italy.

3 La vita comune del clero nei secoli XI et XII, vol. 1, 508, refers to such pieve-canonries as canoniche plebanali. 
to chant the psalms, the law of God and to read the Bible, and this way they become worthy successors to the priests. ${ }^{4}$

In 826, the Council of Rome, under the leadership of Pope Eugene II, ordered a cloister and refectory and other facilities necessary for the use of clergy to be built in all churches so that the clergy can learn the ecclesiastical disciplines. ${ }^{5}$ In his classic book on the Italian pieve, Giuseppe Forchielli wrote that the pievi of Verona anticipated seminaries in which the minor clergy would learn everything pertinent to the religious life within the pieve itself, including their initiation to the holy orders. The archpriest of the pieve had the power to ordain them while they were still in the minor orders, and he would recommend them for ordination to the bishop once they reach the major orders. ${ }^{6}$ This internal promotion also meant that the archpriest would have a special interest in getting the minor clergy in his pieve trained.

\section{The Community School}

The communal life of clergy, particularly in Italy, was enthusiastically encouraged and supported by adherents to the eleventh-century reform movement. Not only would this allow the clergy to perform the night offices together but also, as mentioned in the council decrees cited above, it provided younger clergy with the opportunity to learn from older clergy. But what were the precise settings that enabled peer-based learning? Here we can talk of essentially three different settings: the daily meetings that the younger clergy had with the choirmaster; the religious rites; and the

4 'Ut omnes presbyteri qui sunt in parochiis constituti, secundum consuetudinem quam per totam Italiam teneri cognovimus, iuniores lectores, quantoscumque sine uxore habuerint, secum in domo, ubi ipsi habitare videntur, recipiant, et eos quomodo boni patres spiritualiter nutrientes, psalmos parare, divinis lectionibus insistere et in lege domini erudire contendant, et ut sibi dignos successores provideant et a domino praemia aeterna recipiant'. Quoted in La vita comune del clero nei secoli XI et XII, $59 \mathrm{n}$. 77. The term lector here refers to the rank in the holy orders of clergy, and should not be confused with the later usage of the term in the scholastic milieu.

5 Concilium Romanus (826), 570: 'Necessaria et enim res existit, ut iuxta ecclesiam claustra constituantur, in quibus clerici disciplinis ecclesiasticis vacant. Itaque omnibus unum sit refectorium ac dormitorium seu ceterae officinae ad usu clericorum necessariae. Ministri vero post episcopum super eos tales eligantur, quorum vita atque doctrina illos potius exornet quam dehonestet'.

6 Forchielli, La pieve rurale, 168. 
daily chapter meetings. All three settings, I argue, presented opportunities for the clergy to learn from one another, and I will deal with them more in detail below.

When the term cathedral school is mentioned, we are accustomed to think of famous schools in a few select cathedrals such as Laon, Chartres, or Cologne, which were home to prolific scholars and which produced a remarkable body of theological or philosophical literature. ${ }^{7}$ But alongside these was another kind of school, primarily a school of chanting, which was much more common than the cathedral schools bent on theology and philosophy. Medieval records of pievi, as well as of cathedrals, often mention offices of magister scholasticus, magister scholarium (sometimes maiuscole or magiscolus putting together magister and scole), cantor, or primicerius. Primicerius seems to be a teaching office common in the Early Middle Ages, a senior administrative position, but magister scholarum and cantor continue to exist into the Late Middle Ages as offices that trained the clergy.

In the major cathedrals, the schools of theology and chanting were separate. This was the case in the eleventh-century Milan cathedral, for instance. Of the two schools that the cathedral hosted, one was held in the atrium before the church, exclusively for the cathedral clergy in the minor orders (pueri), who trained in chanting. The other was dedicated to liberal arts, philosophy, and theology, open to pupils from outside of the cathedral also. ${ }^{8}$ These two schools convened in different spaces, had different teachers assigned to them, and consequently had different curricula. We find the schools of theology in important cathedrals such as Pavia, Milan, or Vercelli. Possibly, though not necessarily, such schools of theology in the cathedrals and perhaps other important collegiate schools multiplied after the fourth Lateran Council of 1215, which ordered metropolitan bishops to employ

7 On these type of cathedral schools, see Jaeger, The Envy of Angels.

8 'Scolae vero, ubi cantus magistri ad docendos pueros cottidie conveniebant, in atrio ante ipsius ecclesiae regias duae erant, quae ab archiepiscopo, cum opus erat, mercede data nummorum, scolares a magistris emendabantur secundum quod Ezechiel propheta dicens affirmat: "Extra portam interiorem gazophilacia cantorum". In atrio interiori, quod erat a latere portae respicientis ad aquilonem, philosophorum vero scolae diversarum artium peritiam habentium, ubi urbani et extranei clerici philosophiae doctrinis studiose imbuebantur, erant duae, in quibus ut clerici qui exercitiis tradebantur curiose docerentur, longa temporum ordinatione archiepiscoporum antecedentium, stipendiis a camerariis illius archiepiscopi, qui tunc in tempore erat, annuatim earum magistris honorifice donatis, ipse praesul multoties adveniens, saeculi sollicitudines a quibus gravabatur, a se depellebat, ac magistros ac scolares in studiis adhortans, in palatiis sese demum recipiebat Ambrosianicis'. Beroldus: Sive, Ecclesiae Ambrosianae Mediolanensis kalendarium et ordines, saec. XII; ex Codice Ambrosiano, 155 . 
a theologian to teach theology in the metropolitan churches. The school meant in this decree is this type of school of higher theological learning, not the schools of chant, which, we can assume, existed in the pievi and other great churches over all of Italy prior to the thirteenth century. In fact, Italy seems to have a unique position in that the cathedral schools, and probably also schools of pievi, educated lay people even when they were not destined for clerical profession. And this fact greatly contributed to the higher rate of literacy found among the laity of the Italian cities compared to literacy elsewhere in Europe. ${ }^{9}$

Scholares or schola cantorum literally meant a group or community of chanters, which would have mostly consisted of the clergy in the minor orders, sometimes including also young men or boys who were not clergy. The job of teaching the chant could belong to more than one office. In the cathedral of Padua, the magister scholarium and cantor were two distinct offices, and both were involved in teaching the younger clergy. Young clerics would learn to chant the canonical hours, i.e., the Divine Office, which essentially consisted of chanting the entire Psalter over a week. This should not be thought akin to a pure music class; rather, this teaching must have included instruction in basic Latin grammar and essentially in reading, even if not so much writing. After all, a reading knowledge of Latin was also necessary in order to use liturgical books such as penitentials, missals, prayer books, etc. that were used to perform other divine services; and reading also was a way of aiding and reinforcing the memory. It is well known that the Psalter was used throughout the Middle Ages as a book to teach elementary Latin. ${ }^{10}$

The reason why the pievi in Italy were particularly keen to establish such schools also had to do with clerical ordination. The head of a pieve, the archpriest, usually was in charge of ordaining the clergy in the minor orders, so he had to see that they received the necessary training to make it to the next level of ordination. The link between the archpriest's right to ordain his clergy and the clerical education offered in a pieve goes back to the Early Middle Ages. In 796, the bishop Giso of Modena was advising the

9 On the subject of the education of laity in the schools of clergy see Black, Education and Society, $173-75$.

10 'Ma sarebbe stato molto più facile imparare a memoria, mettiamo, l'intero salterio, se nello stesso tempo si fosse imparato a leggere; e molti documenti confermano che si adoperava il salterio come testo elementare di lettura nel Medioevo.' Bullough, 'Le scuole cattedrali', 116. On Divine Office as a means of teaching music and Latin reading to child oblates in the monasteries, see Boynton, 'Medieval Musical Education', 52-53. Boynton here focuses on the liturgical texts. For the use of psalms in moral instruction, see Mayeski, 'A Mother's Psalter', 139-51. 
archpriest of a pieve that he should be diligent in keeping the community together and should teach boys (in schola habenda et puerorum educandis) so that they receive the learning necessary for clerical ordination. We have bishops issuing similar counsels to other archpriests of pievi in the records of Modena, from 908 and 882. ${ }^{11}$ As for the frequency with which these classes of chanting were held, it is likely that the class met every day, when a magister scholarium was present in a clerical community. In the thirteenth-century Lucca cathedral, the magister scholarum was exempt from singing the Lauds 'on account of the classes which he must hold during the day'. ${ }^{12}$ In the smaller pievi that did not have a designated teacher, presumably one of the elder and more experienced members of the community took on the job of teaching the younger clergy. In such cases, the teaching might have been done with lesser frequency.

At this point, it might be pertinent to address the question of whether this kind of learning can be legitimately considered 'horizontal'. The justifiable objections would be that, after all, here we have a group of students learning from a teacher, not from each other, and the learning takes place in regulated time and space rather than casually. However, the crucial point is that this is still a single clerical community: the teaching is done through regulations established internally. The cathedral or pieve school, whether it be of chanting or of theology, is an institution established by the community and for the community. The teacher and the student belong to the same community, and the learning takes place within the same space. Had the young clergy left the boundaries of the canonry and gone to another institution to be trained there by a teacher who is not a member of his own community - as was the case with university learning, for example - then we could talk of vertical learning. Here, however, there is enough justification to consider a cathedral or pieve school an institution of peer or horizontal learning.

\section{Liturgy as Education}

The second element in the clerical communities that was conducive to horizontal learning is the liturgy. It has been argued that the Gregorian reformers saw liturgy as a tool to educate the laity in doctrinal matters. ${ }^{13}$ However, there has not been sufficient consideration of the educational 
function of liturgy for the clergy. ${ }^{14}$ After all, everything that can be said about how laity learned about the Christian doctrine from the liturgy is true for the clergy as well. As Christianity was built around the life of a single man, Jesus of Nazareth, who was believed to be God at the same time, sanctity could only be achieved by approximation to Christ, his life, and his deeds. The early Christian saints were those who came closest to Christ in their lives and deeds (to his martyrdom especially), and the rites of sanctification for the faithful were essentially re-enactments of key episodes from Christ's life: baptism was a re-enactment of Jesus's baptism by John the Baptist; the Eucharist of his sharing of bread and wine in his last supper with the apostles; and Penance of his suffering on the cross. All these rites developed over a long period of time through the contributions of many prominent monks, bishops, canons, and popes, and all are still evolving to this day. ${ }^{15}$

Christian religious instruction thus was woven into Church rites. Readings from the Gospel, the Epistles, hymns, the lives of saints, and homilies written by the Church Fathers and preached by the priests - all serving to instruct people both in the basic tenets of the Christian faith and in the vices and virtues - were carefully blended into all Church rites. As the twelfth-century Italian theologian Prepositinus of Cremona wrote, the psalms signified good works, while readings during the Mass and Office constituted religious teaching. ${ }^{16}$ Such instruction was not only a means of educating the lay people. The clergy too, as administrators and participants of these rites, received the same instruction and sanctification for salvation; rites were thus as much a means to educate clergy as they were a means to educate laity.

The liturgy observed in a pieve or cathedral was pretty comprehensive. It involved the performance of the Christian rites, including the Divine Office; all the sacraments and blessings given to the laity; and all of these were celebrated by more than one cleric. This is a very important point that distinguishes the canonry from the monastery with regard to horizontal

\footnotetext{
14 For the liturgy as education for laity, see Vitz, 'Liturgy as Education', 20-34; Boynton, 'Training for the Liturgy', 7-20, notably pointed to the importance of liturgy in the doctrinal education of younger monks.

15 For the development of liturgy in the early medieval period, see Hen and Meens, The Bobbio Missal, and Hen, The Royal Patronage of Liturgy. Mons. Enrico Cattaneo made important contributions to the history of liturgy and clerical commnunities in Italy. See for example his 'La vita comune dei chierici e la liturgia', 241-272.

16 Praepositinus of Cremona, Tractatus de officiis, 229: 'Post psalmos, per quos bona opera intelliguntur, sequitur Lectio, per quam fidei doctrina religionis significatur'.
} 
learning. The difference lies precisely in the fact that the clergy in the canonries participate in a number of pastoral services - such as the scrutinities, exorcism, baptism, and last rites - which the monks, not having the cure, do not customarily perform, although there are exceptions and some monasteries did provide care of souls. These pastoral services contain a myriad of theological information; therefore, one might argue that canons and other clergy are exposed through the liturgy of pastoral care to more theology than the monks are in their daily cycle of liturgy.

Among all the liturgical functions, the Divine Office was probably the richest source of learning for the clergy. In any cathedral ordinal, by far the greatest space was accorded to the Divine Office, which was, like the Mass, conducted every day but (unlike the Mass) eight times a day. While there is a fairly large scholarly literature on each of the sacraments of Mass, baptism, marriage, and penance, the Divine Office has been relatively little studied by historians. In medieval historiography, the Office has not been associated with the care of souls, but rather studied within the domain of liturgy. ${ }^{17}$ The late James W. McKinnon, a scholar of liturgy, wrote that 'it is hardly an exaggeration to say that the Western medieval liturgy consisted in the public singing of the Psalter..$^{18}$ Also known as the 'canonical hours', 'Hours', or 'the Office', the Divine Office essentially is a daily cycle of prayer that involves eight periods of chanting such that all $15^{\circ}$ psalms are sung within the course of a week. ${ }^{19}$

The Office was not just yet another Church service; it was the most comprehensive pastoral service offered in a church. It was doctrinal and moral instruction, prayer, praise of God, blessing, and confirmation of faith all bundled into one, and that explains the tremendous importance attached to the chanting of the hours evident both in synodal decrees and in records of episcopal visitations to canonries, where the first question was always whether the canons held all the canonical hours and whether there were any canons negligent of or absent from chanting. ${ }^{20}$ Despite the

17 One of the few essential contributions dedicated to the subject of the Divine Office, Steiner, Baltzer, and Fassler, The Divine Office, contains no article exploring the relevance of the Divine Office to the care of souls.

18 McKinnon, 'The Book of Psalms', 43.

19 Collamore, 'Prelude', 3-11.

20 In the 1276 visitation of the Piacenza cathedral, the denial of distributions to canons who neglect Lauds and Vespers was the first item. Piacenza, Bibl. Cap. 27, f. 50 : 'In primis circa officium divinum ut negligentes et desides excitentur ad bonum, ordinat et statuit quod qui non fuerit in matutinis ante [...] primi psalmi et ad benedictus in fine amittat distributionem illius matutini'. 
obvious importance attached to the Divine Office in medieval records, we, historians, know little about its didactic function. Therefore, before setting out to discuss the various elements of the Divine Office, it might be expedient to give first an example from an ordinal describing the office of a canonical hour. The following is from the Siena cathedral ordinal of 1139 and is a particularly incisive account of the entire ordo of Prime, the first canonical hour of the day. The section is entitled 'Concerning the Meaning and the Mystery of All That Is Said in Prime'.

Prime is celebrated because with the sun in the East, we have to pray for the sun to rise in justice to us, so that, walking in its light, we avoid the darkness of sinners and because the 'Landowner went out early in the morning to hire labourers into his vineyard' [Matt. 20:1]. And note that in all hours this versicle, 'O God, come to my assistance' [Psalm 70], is said first and is taken from the Old Testament. The Ark was surrounded every day by enemies and while it was lifted and carried, Moses was saying 'Arise, O Lord, and all your enemies will scatter and those who hate you will flee before your face' [Book of Numbers 10:35; see Psalm 67:2].Just as the Church endures inside and outside, because we beg God for his help saying 'O God, come to my assistance', similarly in all hours, we say first the 'Glory to God' [a popular hymn: Gloria Patri et Filio et Spiritu Sancto ...] in order to glorify the Trinity: without it we can do nothing. Five psalms follow to strengthen divinely the five senses of the labourer during the day and the reason why we say three psalms after three Glory to Gods is so that the Trinity is glorified in our works and because without faith the worker cultivates in vain, and without faith, the pastor guards the flock in vain. Here the creed (symbolum) is uttered: that is to say, 'Whoever wishes, ${ }^{21}$ which Athanasius, the bishop of Alexandria, when asked by the emperor Theodosius, decreed to eradicate the faithlessness of the heretics and to disseminate the Catholic faith. That is why it is said in Prime, because faith brings forth the beginning of our salvation. And note that in 'Whoever wishes', the people are taught their faith by their pastors. In 'I believe in One $\mathrm{God}^{22}$ everyone confesses their faith like a learned person. Thence, in the

21 This is also known as the Athanasian Creed, Quicumque vult saluus esse: 'Whosoever wishes to be saved, before all things it is necessary that he/she holds the Catholic faith. Which faith except every one do keep whole and undefiled; without doubt he shall perish everlastingly. And the Catholic faith is this: That we worship one God in Trinity, and Trinity in Unity; Neither confounding the Persons; nor dividing the Essence'.

22 The Nicene Creed: 'I believe in one God, the Father Almighty, Maker of heaven and earth, of all things visible and invisible'. 
reading (capitulum), the pastor encourages his sheep and the landowner encourages his labourer so that they do not neglect the work: 'Act strongly' etc. [Acts of the Apostles 2:21]. Then the eager ones say 'Christ, the Son of God. Arise O Lord' [responsory], which really means, make us arise. The prayers that follow are the 'Kyrie eleison', which is said for three reasons: to stop superfluous thoughts, to ask mercy for the sheep who stray and weary labourers, and to postulate help against temptations so that we can invoke securely the Father in the Sunday prayer. 'I have gone astray like a sheep that is lost' [Psalm 118] signifies the sheep that are gone astray and that faith is the road to come back. Then the Apostles' Creed is uttered: 'I believe in God the Father'. After that the Labourer speaks for himself, for the pastors, for the kings, for the people, for the alive and the dead, and 'Have mercy on me O Lord' [Psalm 51] for the penitents and the litanies and prayers for the audience are multiplied, because through such fruits we are reconciled to God. And note that the priest first prays in prostration, and then getting up, he prays standing, which signifies Christ, who first prayed for the sinners living on earth, and then, after His resurrection and ascent to the Heavens, intercedes for us. And just as Christ used to greet his disciples saying 'Peace to you', so does the priest offer the greeting of the prayer. 'Let us bless the Lord' signifies blessing, by which Christ blessed his disciples after resurrection, and then the disciples give their thanks and the final praise, which will be in glory with the deeds of thanks, when Christ after his intercession will give his believers eternal salvation. ${ }^{23}$

23 'De Ratione et Mysterio illorum qua dicuntur ad Primam. Prima ideo celebratur, quia sole oriente postulare debemus solem justitiae nobis oriri, ut in lumine ejus ambulantes, peccatorum tenebras evadamus, et quia "Pater familias primo mane exiit conducere operarios in vineam suam": et nota quod in omnibus horis hic Versiculus "Deus in adjutorium meum intende" praemittitur, et est sumptus a veteri Testamento. Arca enim cotidie circumdabatur ab inimicis, et dum elevabatur, et portabatur, Moyses dicebat "Surge Domine, et dissipentur omnes inimici tui, et fugiant qui oderunt te, a facie tua". Sic et Ecclesia patitur intus, et extra, ideoque Divinum imploramus auxilium dicentes "Deus in adjutorium". Similiter in omnis horis praemittitur "Gloria Patri", ut glorificemus Trinitatem, sine qua nihil possumus. Quinque Psalmi sequuntur ut quinque sensus Operariorum per diem divinitus muniant, vel tres Psalmi sub tribus "Gloriis" sunt comprehensi, eo quod Trinitas in nostris operibus glorificatur, et quia Operarius sine fide frustra vineam colit, et pastor sine fide frustra ovile custodit. Subditur Symbolum fidei: scilicet "Quicumque vult", quod Athanasius Episcopus Alexandrinus, rogatu Theodosii Imperatoris, ad eradicandam haereticorum, perfidiam, et divulgandam fidem catholicam edidit, quod ideo in Prima dicitur, quia fides principium nostrae salutis extitit: et nota quod in "Quicumque vult", populus de fide a pastoribus docetur. In "Credo in unum", fidem suam quasi doctus quilibet confitetur. Deinde in Capitulo Pastor oves, et Pater familias Operarios, ne in labore deficiant, consolatur: "Viriliter agite, quia omnis quicumque invocaverit et cetera". Unde alacres dicunt "Christe Fili Dei. Exurge Christe”, idest fac nos exurgere. Preces, quae sequuntur, scilicet 
This Sienese office of Prime thus starts with a passage from the Gospel to create a dramatic setting with the biblical image of labourers going out to the Lord's vineyard with the first light of the day, i.e., at the time of Prime. Prayers here implore God's help during the day as a means of spiritual fortification and blessing of the body. There follows praise to God in the form of Glory and the reading of a passage from the Gospels; twice there is confirmation of faith through the utterance of the Athanasian Creed and the Apostles' Creed; and finally there is penance as the penitential psalm is uttered.

\section{The Ordinal as a Source for Learning (liber ordinarius)}

What makes the experience of liturgy even more educational for the clergy in the cathedrals and pievi is the presence of a particular liturgical book known as the ordinal or liber ordinarius. An ordinal contains the liturgy of the Mass, baptism, penance, and extreme unction, leaving out confirmation and ordination, which could only be celebrated by a bishop and therefore would belong to a pontifical. Apart from the ordo of sacraments, an ordinal also offers numerous blessings, prayers for various occasions, the ordo of burial, as well as the descriptions of offices within the collegiate church. In addition to containing the entire liturgy of the cathedral throughout the year, including the sacraments, the cathedral ordinals list the duties of the office of priests, deacons, sub-deacons, etc. In the thirteenth-century ordinal of Padua cathedral, for example, we find the job descriptions of the clergy of all ranks and of all major offices such as priests, deacons, sub-deacons, acolytes, cantor, magister scholarium, custodian, etc. ${ }^{24}$ In

"Kyrie eleison", propter tria dicuntur, ad resecandas superfluas cogitationes, ad impetrandam misericordiam propter oves errantes, et operarios fatiscentes, et ad postulandum auxilium contra tentationes, ut possimus in Dominica oratione Patrem securius invocare. Per "Erravi sicut ovis, quae periit", patet quod de ovibus errantibus agitur, et quia via redeundi est fides. Symbolum Apostolorum subditur scilicet; "Credo in Deum Patrem", postea pro se ipso loquitur Operarius, pro Pastoribus, pro Regibus, pro Populo, pro Vivis et Defunctis, et "Miserere mei Deus", pro poenitentibus, et aliquotiens Psalmi Poenitentiales et Litaniae, et Orationes pro Astantibus multiplicantur, quia per tales fructus Deo reconciliamur et nota quod Sacerdos prius prostratus orans, et postea furgens, et stando orans, Christum significat, qui prius conversatus in terris pro Peccatoribus oravit, et post resurgens, et ascendens in Coelum, interpellat pro nobis et sicut Christus discipulos salutavit dicens "Pax vobis", sic Presbyter salutationem Orationi praemittit. "Benedicamus Domino", significat benedictionem, qua Christus discipulis benedixit post Resurrectionem, unde ipsi gratias egerunt, vel finalem laudem, quae erit in gloria cum gratiarum actione, quando Christus post suam interpellationem Fidelibus salutem donabit aeternam'. Ordo ecclesiae Senensis, 436-37.

24 Liber ordinarius, 6-8. 
order to rise up the clerical ladder and be ordained to the next level, every cleric had to learn the duties of the higher orders, and that was only possible through observing the clergy belonging to these higher orders to see how they execute their job.

Liber ordinarius can also be thought of as a principal reference book for liturgy. Almost all Italian cathedral ordinals I have examined not only contain the rites but also - as seen in the example above - take the trouble to explain the meaning of every psalm, every hymn, and every prayer, along with their allegorical significance, as well as why a particular psalm is chanted in a particular hour of the Office or on a particular feast day. This amounts to a tremendous education in Church history and theology. An ordinal is a commentary not just on the psalms but also on the prayers, antiphons, and litanies, through which the reader is taught about Christ's life and his teaching and also about all other parts of the Bible (as in the reference to Moses and the ark in the example above). A cleric who had a sufficient degree of Latin could receive a solid and well-rounded theological education by just sitting down and reading a liber ordinarius. Even if a canon's knowledge of Latin was not sufficient to allow him to read and understand the ordinal, he would still have access to the content of this book through those canons who could read or more obviously the choirmaster or magister scholarium mentioned above. ${ }^{25}$ That is why the medieval canons of Piacenza called their ordinal liber magistri, as it was believed to be a book used primarily by the master of students. ${ }^{26}$ For the master of students and the chanter, the ordinal would serve as a textbook for teaching the text of the Divine Office and other rites to the canons, but while teaching they would also be able to explain the meaning of each element of liturgy in its own setting. The liturgy itself, performed with and within a community, would serve at the same time as training in the Christian doctrine. Thus wrote the ninth-century liturgist-canon Amalar of Metz, who cites Saint Jerome's words to point to the opportunities for learning in the psalms, hymns, and canticles:

'We learn most fully in the Psalter', he [Saint Jerome] says, 'about the difference between a psalm, a hymn and a canticle [...] hymns are those things that preach the strength and majesty of God and forever marvel

26 The codex 65 of the Biblioteca Capitolare of Piacenza (twelfth century) is one of the finest examples of this genre, a towering volume of $45^{\circ}$ folios with dimensions of $485 \times 327 \mathrm{~mm}$. (Liber magistri, ed. Racine, and Liber magistri, ed. Møller Jensen). 
over his favors and deeds [...] Properly, though, psalms have a moral subject, to let us know what we should do and what we should avoid with the instrument of our body. And he who investigates higher things and sets forth as a subtle examiner the concord, order and harmony of the world and all creation - he sings a spiritual canticle'. ${ }^{27}$

The Office, where all the clergy chanted together seven or eight times a day, served as the major venue for the minor clergy to practise what they have learned during the day. This was the time when the younger canons observed the older ones, and the old ones had a chance to observe the young ones and correct their mistakes. In fact, we learn that sometimes this correcting went to extremes. During the 1346 visitation of the cathedral of Udine, some canons revealed the disorderly manner in which the Divine Office was sung. They complained that some of the canons did not show up and that some chatted during the Office. Some older clergy were clamorous and were scolding the younger canons, telling them off during the Office for having chanted incorrectly, sometimes saying things like 'for devil's sake' and thus scandalizing both the clergy and the laity present. ${ }^{28}$

The Office was not only a tool for instruction but also a communal rite that allowed each and every cleric to act as pastor to one another. The pastorality of the Divine Office, the office itself acting as a pastor through the chanting, is explained lucidly by Amalar of Metz with reference to Prime:

For just as sheep (who are kept at night in the fold, but who leave the village after their early-morning shelter to pasture in the wide fields) must have a shepherd to defend them from ravaging wolves, so must we, upon rising in the morning at the Lord's command, also have a pastor and a teacher to introduce us to his commandments and defend us from the wolves that we read about in the Gospel according to John: "The wolf catches and scatters the sheep' [John 10:12]. ${ }^{29}$

27 Amalar of Metz, Liber officialis, vol. 2, 329.

28 'Die V dicti mensis decembris in dicto loco. Dominus Nicolaus de Pola, canonicus dicte ecclesie, adiuratus ut supra, super primo capitulo, eo sibi lecto, respondit quod in officio divino non novit aliud defectum nisi quod plures clerici, dum sunt in choro frequenter loquuntur et impediunt officium divinum. Item sunt aliqui qui vociferant in choro, dicentes alicui clerici: facias vel non facias sic et sic, in nomine diaboli, ex quo verbo scandaliçantur clerici et layci'. Visitatio Ecclesie Capituli Utinensis (1346), 49.

29 Amalar of Metz, Liber officialis, vol. 2, 307. Throughout the section on the Divine Office, Amalar represents the act of chanting as a pastoral act. In his discussion of why Prime lacks a Gospel reading, he similarly says that 'it was not passed over in vain; rather, since the pastor at 
The prayers at each of the hours were to act as a kind of spiritual shield for those who uttered them, a shield that would only be effective until the next hour of chant..$^{30}$ The office of Prime cited above includes a reaffirmation of faith in the form of the Athanasian creed; it implores God's help and it offers the best-known penitential Psalm 51, 'O God, have mercy on me', as a way of starting the day with strong faith and in a state of grace. Seen in this light, one can understand better the insistence of many Church reformers, who strove to keep the clergy pure and devout, on the chanting of all canonical hours.

As mentioned above, in addition to the Divine Office, many other pastorally oriented church services provided a venue for peer-based learning. Among the important ones are the Mass, baptism, and penance in particular. The Italian scholar Ferminio Poggiaspalla argued that the rite of baptism - which, in Italy, until the Late Middle Ages, included the rite of scrutinies and exorcism - provided training for the clergy as well for the laity. ${ }^{31}$ In order to understand how and why this particular rite served especially as a framework for the clergy, one has to look at how it was performed. In the Italian rite of baptism, observed in many pievi and cathedrals, the catechumens - that is, the infants to be baptized - would come to the Church once a week for the three weeks before Easter Saturday, as they would go through the scrutinies and exorcism before the actual baptism. During the rite of scrutinies, the priest would ask those to be baptized what they seek (they would answer the grace of God) and what the grace of God means (remission of sins and the eternal life). Since the catechumens themselves were infants or toddlers, the answers to these questions would be given by the acolyte accompanying the priest on behalf of the faithful. In fact, the rite would have continued after the catechumens left, as the priest and the assisting clergy prayed together. Similarly, the minor clergy would be present with the priest during the rite of public penance, and of burial, after the corpse of the deceased was brought into the Church. All these rites contain a substantial amount of theological premises, attributes of God, and readings from the Bible, particularly the book of Job..$^{2}$

that point wishes to suggest the figure of a teacher, he omits his teaching to teach that every teacher should first work and then teach'. Amalar of Metz, Liber officialis, vol. 2, 335 .

30 Amalar of Metz, Liber officialis, vol. 2, 327. 'None keeps us through the ninth hour and the tenth and the eleventh'. Amalar of Metz, Liber officialis, vol. 2, 353. See also the Regula Sancti Chrodegangi, chap. 129, 157: 'That is why it is appropriate for us to celebrate the Divine Office at these hours, with psalmody and prayer, so that by doing so we may be prepared and free from anxiety, whether we die, or whether the Lord comes'.

31 Poggiaspalla, La vita comune del clero, 15.

32 See for example Lambot, North Italian Services of the Eleventh Century. 
The particular nature of the canonry as a pastoral institution made peer-based learning all the more crucial. A clerical career in a canonry meant that the clergy would start with the first of the holy orders and then rise up to the order of priesthood, and every canonical order in a clerical community had distinct duties and responsibilities. The community as a whole was responsible for training the minor clergy, not just in chanting the psalter but in every other type of pastoral duty that the clergy in various ranks has to perform. Clergy had to learn how to baptize, how to confess, how to give last rites, etc.

\section{Chapter as an Institution of Horizontal Learning}

The third venue for peers to learn from each other was the daily chapter meetings in the canonries. The rules written for canons, such as that by Bishop Chrodegang of Metz (d. 766) and the early ninth-century Institutio canonicorum Aquisgranensis, called for the clergy to convene daily. This is how Chrodegang's rule introduced the obligation:

It is required that all the canonical clergy come to Chapter, where they will hear the Word of God, and this little rule of ours, which we have written with God's help for their own benefit and for their souls' salvation. Every day they should read one chapter, except on Sundays, Wednesdays and Fridays when they shall read at Chapter some tracts and other homilies or whatever may edify the hearers. We have said that all should come to Chapter every day, both that the soul may hear the Word of God, and also that the bishop, archdeacon or whoever is in charge may give whatever commands he has to command, may correct what needs correction and ensure that what needs to be done is done. ${ }^{33}$

As such, the chapter meetings present ample opportunities for the transfer of religious and moral knowledge among members of the community. There are the readings from the Bible, readings from the Rule that the community follows, there are homilies, and there is also correction of community members by the seniors or leaders of the community. Unfortunately, we do not have the records of these meetings, but it is not hard to imagine that the members of the chapters learned from everything talked about in the chapter and that it served as a moral and religious guide to the community 
as a whole. The public confession of venial sins during the chapter meetings was certainly a moral education, and hearing what penance the archpriest or the prepositus (i.e., the head of the community) asked from the sinner provides experience in hearing private confessions.

\section{Conclusion}

In the Italian canonries, the cathedral, and the pieve, we find an institution that, from its very origins onward, appreciated and utilized horizontal learning as an effective way to train the clergy in the absence of seminaries and ad hoc schools. The major means of dissemination of knowledge was through the liturgy of the pastoral services, as all teaching was directed to making the clergy effective pastors. This system only starts to break down in the thirteenth century, when the clergy in many canonries no longer lived together and when the theological training was outsourced to the emerging schools of mendicants and universities. The outcry of the Parisian theologians at the end of the twelfth century concerning the lack of theology schools and their denunciation of ignorant clergy has to be taken with a grain of salt considering the community learning in the Italian cathedrals and pievi.

\section{About the author}

Neslihan Şenocak is an associate professor of history at Columbia University. She specializes in medieval religious, intellectual, social and political history. Her research and teaching focuses on popular religion, political theology, criminal justice, medieval Italian communes and in particular the way the religious intellectuals influenced theopolitical institutions of the medieval Latin Christendom. She was a fellow of I Tatti, Harvard University Center for Italian Renaissance Studies (2013-14) and of National Humanities Center (2015-2016). She is the author of The Poor and the Perfect: The Rise of Learning in the Franciscan Order 1209-1310, published in 2012 by the Cornell University Press. At present she is co-editing two volumes: Italy and Christianity, 1050-1300 with Agostino Paravicini Bagliani, to be published by Cornell UP, and Teacher as Shepherd: Theology and Care of Souls at the time Lateran IV (1215) with Clare Monagle, to be published by Brepols. She is also writing her second monograph, Care of Souls in Medieval Italy, 6oo-130o, to be published with Cornell UP. She has published several articles on the 
medieval Franciscans, in particular their learning, books and poverty, and on the religious confraternities in medieval Italy. 